\title{
CD34 function in intracellular signaling and mucosal inflammatory disease development
}

\author{
Matthew Gold ${ }^{1 *}$, Marie-Renee Blanchet ${ }^{1}$, Lionel A Samayawardhena ${ }^{2}$, Jami Bennett ${ }^{1}$, Steven Maltby ${ }^{1}$, \\ Catherine J Pallen², Kelly M McNagny ${ }^{1}$ \\ From AllerGen NCE Inc.'s Fifth Annual Research Conference: Innovation from Cell to Society \\ Québec City, QC, Canada. 7-9 February 2010
}

\section{Objective/purpose}

CD34 is a cell surface sialomucin that has been the subject of extensive interest, largely based on its use as a marker for hematopoietic stem cells (HSCs) and vascular endothelia. Despite the almost ubiquitous use of CD34 as a HSC marker, little is known about its cellular function. Our lab was the first to show that CD34 is also highly expressed on mature murine mast cells, and we and other groups have found it to be expressed on eosinophils and dendritic cells. We found that mast cells derived from $\mathrm{Cd} 34^{-/-}$mice exhibit a marked increase in cell-cell aggregation. Moreover, when $C d 34^{-/}$mice were challenged in a mouse model of asthma, immune cell accumulation in the lung was drastically reduced, while the number of immune cells in the lung at baseline was similar to that of their wild-type counterparts. We have since found that deletion of the $\mathrm{Cd} 34$ gene in mice renders these animals resistant to a wide range of other mucosal inflammatory diseases, including hypersensitivity pneumonitis (HP), ulcerative colitis, salmonella infection and intestinal tumor development. Our objectives are to examine the specific role of CD34 in cellular function and to see whether or not CD34 is a viable therapeutic target to treat mucosal inflammatory diseases.

\section{Methods}

Bone marrow mast cells were derived from wild-type and $\mathrm{Cd} 34^{-/-}$mice after four week culture in media containing IL-3. Changes in migration, polarization, degranulation and cytokine production were measured after c-kit and/or FceRI stimulation. For in vivo studies, we

\footnotetext{
* Correspondence: mgold@brc.ubc.ca

${ }^{1}$ The Biomedical Research Centre, University of British Columbia, Vancouver, B.C., Canada

Full list of author information is available at the end of the article
}

developed transgenic mice that lack the mouse $C d 34$ gene and instead express, in all the appropriate tissues, the human $C d 34$ gene. These mice were put through a standard Ovalbumin (OVA) induced asthma model. Airway inflammation severity was assessed by analysis of the broncho-alveolar lavage (BAL) content, histological scoring of H\&E stained lung sections and cytokine production of isolated lung inflammatory cells in response to OVA.

\section{Findings}

Preliminary experiments have suggested that CD34 plays an important role in c-kit signaling events and FceRI induced degranulation. Initial testing of our $h C d 34^{t g}$ mice has shown that expression of the human $C d 34$ gene in CD34-deficient mice is sufficient to regain susceptibility to both allergic asthma and HP in mouse CD34-deficient animals. These findings suggest that human CD34 serves a similar function to mouse CD34 in both animal disease models.

\section{Deliverables and relevance}

We show that in mast cells, CD34 plays an important role in regulating cellular signaling through both the ckit and FceRI pathways. In addition, we have demonstrated that expression of human CD34 serves a similar function to mouse CD34 in both asthma and HP, providing a proof-of-concept to assess therapeutics targeting human CD34 in $h C d 34^{t g}$ mice as a humanized mouse model to treat these diseases. Allergic asthma affects more than $10 \%$ of all North Americans and is a major cause of hospitalization of children. Current therapeutics are largely ineffective for chronic asthma and the most potent therapies can carry a number of side effects. CD34 could represent a new therapeutic target, and since we have shown that CD34 plays a role in the 
susceptibility to a wide range of mucosal inflammatory diseases, it is likely that it could serve as a viable treatment for a number of diseases.

\section{Author details}

${ }^{1}$ The Biomedical Research Centre, University of British Columbia, Vancouver, B.C., Canada. ${ }^{2}$ The Child \& Family Research Institute, University of British

Columbia, Vancouver, B.C., Canada.

Published: 26 November 2010

doi:10.1186/1710-1492-6-S3-P15

Cite this article as: Gold et al:: CD34 function in intracellular signaling

and mucosal inflammatory disease development. Allergy, Asthma \&

Clinical Immunology 2010 6(Suppl 3):P15

Submit your next manuscript to BioMed Central and take full advantage of:

- Convenient online submission

- Thorough peer review

- No space constraints or color figure charges

- Immediate publication on acceptance

- Inclusion in PubMed, CAS, Scopus and Google Scholar

- Research which is freely available for redistribution

Submit your manuscript at www.biomedcentral.com/submit 